\title{
Location and Activity of \\ the Respiratory Enzymes of Baker's Yeast and Brewer's Bottom Yeast Grown under Anaerobic and Aerobic Conditions
}

\author{
By T. NURMINEN AND H. SUOMALAINEN \\ Research Laboratories of the State Alcohol Monopoly (Alko), Helsinki, Finland
}

(Accepted for publication Io April 1968)

SUMMARY

The activity of the electron-transport enzymes of baker's yeast or brewer's bottom yeast, grown under anaerobic conditions, was very low. When anaerobic baker's yeast was cultured aerobically to the mid-exponential phase with limited carbon source, the activity of the electron-transport enzymes increased 3- to Io-fold and, correspondingly, the activity in the stationary phase rose 10- to 50 -fold. For brewer's bottom yeast the increase of activity induced by oxygen in the aerobic stationary phase was only about 3- to 4-fold and the activity was clearly lower than that of baker's yeast. The activity of the electron-transport enzymes accumulated in the $10,000 \mathrm{~g}$ sediment, which under aerobic conditions contained $60-80 \%$ of the total activity; the $\mathrm{NADPH}_{2}$ oxidase system formed an exception. The activity of the enzymes of the citric acid cycle also increased under aerobic conditions but only 2- to Io-fold in baker's yeast of the aerobic stationary phase; in brewer's bottom yeast the increase during oxygen adaptation was proportionally greater. The bulk of the enzymes of the citric acid cycle were found in the postmitochondrial supernatant, while the $10,000 \mathrm{~g}$ sediment contained 20 to $40 \%$ of the total activity.

The $10,000 \mathrm{~g}$ sediment of anaerobically grown baker's yeast contained mitochondrial precursors, while the $10,000 \mathrm{~g}$ sediment from the aerobic exponential phase contained mitochondria with a more developed structure, showing a respiratory control ratio of $I \cdot 4-I \cdot 7$ with several substrates. The internal structure of the mitochondria was not completely developed until the aerobic stationary phase, where the uptake of oxygen with several substrates also increased many fold.

\section{INTRODUCTION}

The existence of mitochondria in yeast cells has been clearly proved by electron microscopy (e.g. Vitols, North \& Linnane, I96I) and by isolating mitochondria from yeast cells disrupted by mechanical means (e.g. Vitols \& Linnane, 196I) or by enzymic methods (Duell, Inoue \& Utter, I964; Ohnishi, Kawaguchi \& Hagihara, I966). It is found that yeast grown anaerobically on glucose loses its capacity for oxidation (Tustanoff \& Bartley, 1962). In the presence of oxygen and at a low glucose concentration respiration again takes place. Electron microscopy has revealed that besides the development of respiration, changes appear in the cell structure of the yeast, such as the formation of mitochondrial precursors and their further development to mitochondria (Yotsuyanagi, I962; Wallace \& Linnane, I964; Polakis, Bartley \& Meek, 1964). Alterations in respiratory particles and in various characteristic enzymic activities on release from glucose repression have been studied by Jayaraman, Cotman, 
Mahler \& Sharp (1966). We have investigated the activity of the electron-transport enzymes and the enzymes of the citric acid cycle in baker's yeast and brewer's bottom yeast grown under anaerobic and aerobic conditions, as well as their location in the yeast cell, using for cell fractionation the spheroplast method (Nurminen, Oura \& Suomalainen, 1965; Suomalainen, Nurminen \& Oura, 1967), by which it is possible to isolate subcellular particles in a much less damaged condition than when prepared by methods of mechanical disruption.

\section{METHODS}

Growth of yeast. Anaerobically cultured baker's yeast, stage $\mathrm{R}_{3}$, produced at the Rajamäki Factories of the Finnish State Alcohol Monopoly and brewer's bottom yeast obtained from the brewery Sinebrychoff Ltd., Helsinki, were used as seed yeasts $(0.3 \mathrm{~g}$. $/ 1$. of baker's yeast or $0.6 \mathrm{~g} . / 1$. of brewer's bottom yeast). The growths were made in White medium (I954) at $30^{\circ}$. When the availability of the carbon source limited the growth, baker's yeast reached the mid-exponential phase after Io hr, the yield being $6 \mathrm{~g}$./1. under anaerobic and Io g./l. under aerobic conditions. For the experiments on the aerobic stationary phase, baker's yeast was grown for $20 \mathrm{hr}$, the yield being $29 \mathrm{~g}$. $/ 1$. Brewer's bottom yeast took $17 \mathrm{hr}$ to the exponential phase with a yield of $5 \mathrm{~g}$./1., and 2 days to the aerobic stationary phase with a yield of $27 \mathrm{~g}$. $/ \mathrm{l}$. In aerobic growth $\mathrm{I}$ 1. of air per minute and per litre was forced through the medium, and the anaerobic conditions during growth were obtained by passing a stream of oxygenfree nitrogen from which the traces of oxygen had been removed by alkaline pyrogallol through the growth medium. After growth, the yeast was centrifuged and washed several times with cold water, and used immediately for preparation of spheroplasts. From the anaerobic yeasts the spheroplasts were prepared by using the shortest possible time of digestion in a tightly closed vessel in order to avoid adaptation to respiration.

Preparation of spheroplasts. The yeast cells were suspended to a $10 \%$ suspension

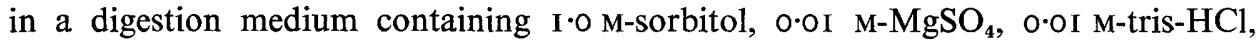
pH 7.5. 'Suc digestif d'Helix pomatia' (L'Industrie Biologique Française, Gennevilliers, Seine, France) was centrifuged at $3000 \mathrm{~g}$ for $\mathrm{I} 5 \mathrm{~min}$. and $5 \% \mathrm{v} / \mathrm{v})$ of this enzyme solution was added to the suspension, which was then incubated at $30^{\circ}$ for the time reported. For yeast cells in the aerobic stationary phase 2-mercaptoethanol treatment was used before digestion. In this procedure the yeast was suspended to $10 \%$ in the digestion medium, $0.0 \mathrm{I}$ M-2-mercaptoethanol was added and the suspension incubated at room temperature for $30 \mathrm{~min}$., after which the yeast was washed by centrifugation 3 times with cold digestion medium, and the digestion proceeded as above. The formation of spheroplasts was studied by phase-contrast microscopy and by measuring the extinction (Nurminen et al. 1965) as well as by determining, in connexion with fractionation, the amount of protein released into the $1000 \mathrm{~g}$ supernatant. Thus, the anaerobic and aerobic log.-phase yeast cells were digested for 60 and 90 minutes respectively and the yeast in the aerobic stationary phase, after pretreatment with 2-mercaptoethanol, for $3 \mathrm{hr}$. Instead of true protoplasts, spheroplasts, i.e. osmotically sensitive, digested cells with some cell wall remaining, were partly used in order to protect the inside of the cell against the digestion liquid.

Fractionation. The spheroplasts were centrifuged at $1000 \mathrm{~g}$ for $\mathrm{I}$ o $\mathrm{min}$. and washed twice by centrifugation with cold digestion medium. The fractionation was essentially 
accomplished to the method of Duell et al. (1964). The spheroplasts were suspended in a hypotonic medium (medium $\mathrm{A}$ ), containing $0.25 \mathrm{M}$-sucrose, $0.02 \mathrm{M}$-potassium phosphate buffer ( $\mathrm{pH} \mathrm{6.8)} \mathrm{and} \mathrm{0.00I} \mathrm{M-EDTA} \mathrm{and,} \mathrm{thus,} \mathrm{lysis} \mathrm{of} \mathrm{the} \mathrm{spheroplasts} \mathrm{was}$ caused by the osmotic shock. The suspension was homogenized for $30 \mathrm{sec}$. in a PotterElvehjem tissue homogenizer. The remaining whole cells, the nuclei and cell debris were removed by centrifugation at $1000 \mathrm{~g}$ for $\mathrm{I} 0 \mathrm{~min}$. It was possible to increase the yield in the $1000 \mathrm{~g}$ supernatant by repeated suspension of the $1000 \mathrm{~g}$ sediment in medium A, followed by slight homogenizing and centrifuging at $1000 \mathrm{~g}$ and, in some cases, this method was used. In order to prepare the mitochondrial fraction or the corresponding anaerobic sediment, the $1000 \mathrm{~g}$ supernatant was centrifuged at $10,000 \mathrm{~g}$ for $10 \mathrm{~min}$. The $10,000 \mathrm{~g}$ sediment obtained was also washed by centrifugation, usually twice, by suspending in a medium, containing $20 \%$ sucrose, $0.02 \mathrm{M}$-potassium phosphate buffer (pH 6.8) and 0.00I M-EDTA. When necessary on the basis of phasecontrast microscopy, the debris of the $1000 \mathrm{~g}$ sediment was removed by repeating the I000 $g$ centrifugation. The washings of sediments were combined with the corresponding supernatants.

Analytical methods. The protein was determined by the biuret method (Racusen \& Johnstone, 196I) with crystalline serum albumin as reference. The dry matter of the yeast was determined gravimetrically.

Determination of the enzyme activities. The fractions isolated for enzyme determinations were kept overnight in I to $2 \mathrm{ml}$. lots (about $20 \mathrm{mg}$. protein per ml.) at $-20^{\circ}$ and only thawed once. However, cytochrome $c$ oxidase and succinate cytochrome $c$ reductase were measured immediately after fractionation, since their activity was found to decrease during storage. The enzyme activities of the seed yeast were determined in the homogenate obtained by shaking in a Mickle disintegrator with Ballotini beads for $30 \mathrm{~min}$. at $4^{\circ}$.

The activity of cytochrome $c$ oxidase was measured by observing the rate of enzymatic oxidation for cytochrome $c$ (Cooperstein \& Lazarow, I95I; Yonetani \& Ray, 1965) reduced by the method of Chantrenne (1955). $\mathrm{NADH}_{2}$ cytochrome $c$ reductase and succinate cytochrome $c$ reductase were determined by registering the reduction of cytochrome $c$ in a system where cytochrome $c$ oxidase was inhibited with cyanide (Green \& Ziegler, 1963). The $\mathrm{NADH}_{2}$ oxidase system was examined by the method of Green \& Ziegler (1963) and the $\mathrm{NADPH}_{2}$ oxidase system correspondingly, with $\mathrm{NADPH}_{2}$ as substrate. The activities of the primary $\mathrm{NADH}_{2}$ dehydrogenase and succinate dehydrogenase were determined by using potassium ferricyanide as electron acceptor in the presence of cyanide (Rabinowitz \& DeBernard, I957). NAD-malic dehydrogenase was determined according to Ochoa (I955), NADP- and NAD-isocitrate dehydrogenase according to Kornberg (I955 $a, b$ ), and fumarase (Racker, 1950; Massey, 1955) and aconitase (Racker, 1950; Anfinsen, 1955) according to Racker. The enzyme activities were determined spectrophotometrically at $25^{\circ}$ by following the changes of extinction at 15 -second intervals. The references were measured without the sample or without the substrate.

Measurement of oxygen consumption. The uptake of oxygen in some substrates was measured polarographically at $25^{\circ}$, using vibrating platinum electrode (Oxygraph, Gilson Medical Electronics, Middleton, Wisconsin, U.S.A.). The reaction medium contained 250 mM-sucrose, 20 mM-potassium phosphate buffer ( $\mathrm{pH} 6.8$ ), I mM-EDTA and ro mM-KCl. Succinate, $\alpha$-ketoglutarate, isocitrate, citrate, ethanol or lactate was 
used as substrate in a concentration of $10 \mathrm{mM}$; for pyruvate and malate the concentration was $5 \mathrm{mM}$, and for $\mathrm{NADH}_{2} 0.5 \mathrm{~mm}$. The mitochondrial concentration in the assay was 0.14 to $\mathrm{I} \cdot 25 \mathrm{mg}$. protein per $\mathrm{ml}$. of reaction mixture on a total volume of $2.5 \mathrm{ml}$.

Electron microscopy. After fixation with osmium tetroxide the samples were dehydrated with successive alcohol concentrations and propylene oxide before being embedded in epoxy resin. Electron micrographs of thin sections were taken with a Siemens Elmiskop I or a Philips EM 200 electron microscope.

\section{RESULTS AND DISCUSSION}

Electron-transport enzymes. The specific activities of the electron-transport enzymes in homogenates and subcellular fractions of anaerobically and aerobically grown baker's yeast and brewer's bottom yeast are presented in Table I. The activity of the electron-transport enzymes is very low under anaerobic conditions in both baker's yeast and brewer's bottom yeast. When baker's yeast had grown aerobically under conditions when the carbon source was limited until the middle exponential phase, the activity of the electron-transport enzymes in the cell homogenates had increased 3- to Io-fold, and reached its maximum, Io- to 50-fold, in the aerobic stationary phase. A similar, although clearly lower, oxygen-induced increase of activity was observed in brewer's bottom yeast, being in the aerobic stationary phase only 3- to 4-fold.

$\mathrm{NADH}_{2}$ cytochrome $c$ reductase was usually more active than succinate cytochrome $c$ reductase. The same phenomenon was observed with the corresponding primary dehydrogenases when potassium ferricyanide was used as electron acceptor.

The activity of $\mathrm{NADPH}_{2}$ oxidase in aerobic log.-phase cells of baker's yeast was only a fifth of that of $\mathrm{NADH}_{2}$ oxidase, and the activities also differed in other ways. The $\mathrm{NADPH}_{2}$ oxidase activity was essentially the same in baker's yeast grown to the exponential phase under both anaerobic and aerobic conditions and only 10 to $18 \%$ of the total activity was found in the $10,000 \mathrm{~g}$ sediment. According to Schatz \& Klima (1964), the $\mathrm{NADPH}_{2}$ oxidase system in yeast is associated with the microsomal fraction, but $\mathrm{NADPH}_{2}$ oxidase activity is also found in the mitochondrial fraction (Schuurmans Stekhoven, 1966).

By electron microscopy it has been established that the presence of oxygen is necessary for the synthesis of mitochondria in yeast (Linnane, Vitols \& Nowland, 1962; Wallace \& Linnane, 1964), at least when glucose is used as carbon source. Studies on the enzyme activities in homogenates and electron micrographs of whole cells have revealed that glucose in high concentration represses the synthesis of respiratory enzymes and the development of mitochondria (Yotsuyanagi, 1962; Polakis, Bartley \& Meek, 1964). This is in agreement with the observation that the activity of the electron-transport enzymes increased also in the log.-phase cells during aerobic growth on a medium containing a lowered concentration of glucose (Table I). The greatest proportional increase occurred in the activity of succinate cytochrome $c$ reductase which, according to Schatz (I963), is very sensitive to conditions inhibiting the development of mitochondria and is not to be found in the mitochondrial precursors.

In all the fractionations, the specific activity of the electron-transport enzymes was highest in the $10,000 \mathrm{~g}$ sediment (Table I), and depended on the growth conditions in 
Table I. Specific activities of some electron-transport enzymes in homogenates and subcellular fractions of baker's yeast and brewer's bottom yeast, grown under varying conditions

\begin{tabular}{|c|c|c|c|c|}
\hline & $\begin{array}{c}\text { Cytochrome } c \\
\text { oxidase }\end{array}$ & $\begin{array}{l}\text { Succinate } \\
\text { cytochrome } c \\
\text { reductase }\end{array}$ & $\begin{array}{l}\mathrm{NADH}_{2} \\
\text { cytochrome } c \\
\text { reductase }\end{array}$ & $\begin{array}{c}\mathrm{NADH}_{2} \\
\text { oxidase }\end{array}$ \\
\hline \multicolumn{5}{|l|}{ Baker's yeast } \\
\hline Seed yeast homogenate & $0.003^{*}$ & 0.004 & 0.003 & 0.012 \\
\hline $\begin{array}{l}\text { Anaerobic culture } \\
\text { Homogenate } \\
\text { I0,000 } g \text { sediment } \\
\text { I0,000 } g \text { supernatant }\end{array}$ & $\begin{array}{l}0.004 \\
0.014 \\
0.000\end{array}$ & $\begin{array}{l}0.001 \\
0.005 \\
0.001\end{array}$ & $\begin{array}{l}0.012 \\
0.046 \\
0.006\end{array}$ & $\begin{array}{l}0.019 \\
0.104 \\
0.011\end{array}$ \\
\hline $\begin{array}{l}\text { Aerobic, middle exponer } \\
\text { Homogenate } \\
\text { 10,000 } g \text { sediment } \\
\text { I0,000 } g \text { supernatant }\end{array}$ & $\begin{array}{r}\text { l phase } \dagger \\
0.042 \\
0.139 \\
0.010\end{array}$ & $\begin{array}{l}0.005 \\
0.022 \\
0.002\end{array}$ & $\begin{array}{l}0.038 \\
0.140 \\
0.010\end{array}$ & $\begin{array}{l}0.066 \\
0.176 \\
0.024\end{array}$ \\
\hline $\begin{array}{l}\text { Aerobic, exponential ph } \\
\text { Homogenate } \\
\text { I0,000 } g \text { sediment } \\
\text { I0,000 } g \text { supernatant }\end{array}$ & $\begin{array}{l}0.042 \\
0.118 \\
0.026\end{array}$ & $\begin{array}{l}0.025 \\
0.123 \\
0.004\end{array}$ & $\begin{array}{l}0.054 \\
0.660 \\
0.051\end{array}$ & $\begin{array}{l}0.054 \\
0.400 \\
0.055\end{array}$ \\
\hline $\begin{array}{l}\text { Aerobic, stationary phas } \\
\text { Homogenate } \\
\text { I0,000 } \mathrm{g} \text { sediment } \\
\text { I0,000 } \mathrm{g} \text { supernatant }\end{array}$ & $\begin{array}{l}0.205 \\
I \cdot 095 \\
0.1 \text { I I }\end{array}$ & $\begin{array}{l}0.028 \\
0.245 \\
0.011\end{array}$ & $\begin{array}{l}0.226 \\
I \cdot 905 \\
0.095\end{array}$ & $\begin{array}{l}0.174 \\
1.029 \\
0.097\end{array}$ \\
\hline Brewer's bottom yeast & & & & \\
\hline Seed yeast homogenate & 0.008 & 0.000 & 0.005 & 0.005 \\
\hline $\begin{array}{l}\text { Anaerobic culture } \\
\text { Homogenate } \\
\text { I0,000 } \mathrm{g} \text { sediment } \\
\text { 10,000 } \mathrm{g} \text { supernatant }\end{array}$ & $\begin{array}{l}0.023 \\
0.067 \\
0.002\end{array}$ & $\begin{array}{l}0.005 \\
0.017 \\
0.000\end{array}$ & $\begin{array}{l}0.007 \\
0.011 \\
0.004\end{array}$ & - \\
\hline $\begin{array}{l}\text { Aerobic, exponential phe } \\
\text { Homogenate } \\
\text { I0,000 } g \text { sediment } \\
\text { I0,000 } g \text { supernatant }\end{array}$ & $\begin{array}{l}0.044 \\
0.229 \\
0.028\end{array}$ & $\begin{array}{l}0.008 \\
0.085 \\
0.000\end{array}$ & $\begin{array}{l}0.004 \\
0.008 \\
0.006\end{array}$ & - \\
\hline $\begin{array}{l}\text { Aerobic, stationary phas } \\
\text { Homogenate } \\
10,000 \mathrm{~g} \text { sediment } \\
10,000 \mathrm{~g} \text { supernatant }\end{array}$ & $\begin{array}{l}0.078 \\
0.100 \\
0.058\end{array}$ & $\begin{array}{l}0.016 \\
0.018 \\
0.014\end{array}$ & $\begin{array}{l}0.022 \\
0.051 \\
0.021\end{array}$ & $\begin{array}{l}0.037 \\
0.051 \\
0.024\end{array}$ \\
\hline
\end{tabular}

* Specific activities expressed as $\mu$ moles of transformed substrate or electron acceptor per minute per mg. protein. $5 \%$ (initial conc.) sucrose used as carbon source.

$\dagger$ Actual carbon source concentration about $2 \%$.

\# Actual carbon source concentration about $0.6 \%$.

the same way as in the homogenates. Table 2 shows the distribution of the total activity in aerobically grown baker's yeast cells. The $10,000 \mathrm{~g}$ sediment contained $70-80 \%$ of the total activity of cytochrome $c$ oxidase, succinate cytochrome $c$ reductase and $\mathrm{NADH}_{2}$ cytochrome $c$ reductase and about $60 \%$ of the total activity of the $\mathrm{NADH}_{2}$ oxidase. The latter could be inhibited by addition of antimycin A to $90 \%$ in the homogenate and completely in the $10,000 \mathrm{~g}$ sediment of log.-phase cells. Hence $70 \%$ of the $\mathrm{NADH}_{2}$ oxidase activity, which was inhibited by antimycin $\mathrm{A}$, was located in the $10,000 \mathrm{~g}$ sediment. The electron-transport enzymes investigated are found to be typical of electron-transport particles isolated from yeast by mechanical disintegration (Biggs \& Linnane, 1963; Mackler et al. 1962; Mahler, Mackler, Grandchamp \& 
Slonimski, 1964) and thus also of mitochondria. By centrifugation of homogenate of mechanically disrupted baker's yeast cells at $26,300 \mathrm{~g}$ for $15 \mathrm{~min}$., Schatz, Tuppy \& Klima (1963) obtained a sediment from which they have isolated a mitochondrial fraction and which contained $89 \%$ of the total activity of $\mathrm{NADH}_{2}$ oxidase and $88 \%$ of that of cytochrome $c$ oxidase. Duell et al. (1964) have reported that the mitochondrial fraction separated from yeast by means of the spheroplast method (at a noticeably lower $g$ value, $5000 \mathrm{~g}$ for $20 \mathrm{~min}$.) contains almost all the cytochrome $c$ oxidase activity. The conclusion can be drawn that the danger of damaging the mitochondria is markedly smaller when the spheroplast method is used than with methods of mechanical disintegration. Further, the recovery of the electron-transport enzymes, found in the fractions of the log.-phase cells, corresponded to 90 to $110 \%$ of the total activity of the homogenate before fractionation. Thus, the activity of the electron transport enzymes found in the post-mitochondrial supernatant apparently does not originate from mitochondria but from other parts of the cell, perhaps from mitochondrial precursors or other membraneous parts.

Table 2. Distribution of total activities of some electron-transport enzymes and enzymes of the citric acid cycle in aerobically grown baker's yeast

Aerobic baker's yeast

\begin{tabular}{|c|c|c|c|c|c|c|c|c|}
\hline & \multicolumn{8}{|c|}{ Aerobic baker's yeast } \\
\hline & \multicolumn{4}{|c|}{$\begin{array}{l}\text { Middle exponential phase } \\
\text { I0,000 } \mathrm{g}\end{array}$} & \multicolumn{4}{|c|}{$\begin{array}{l}\text { Stationary phase } \\
\text { I0,000 } g\end{array}$} \\
\hline & \multicolumn{2}{|c|}{$\overbrace{}^{\text {Supernatant }}$} & \multicolumn{2}{|c|}{ Sediment } & \multicolumn{2}{|c|}{$\overbrace{}^{\text {Supernatant }}$} & \multicolumn{2}{|c|}{ Sediment } \\
\hline & $\begin{array}{c}\text { Total } \\
\text { activity* }\end{array}$ & $\% \dagger$ & $\begin{array}{c}\text { Total } \\
\text { activity* }\end{array}$ & $\% \dagger$ & $\begin{array}{c}\text { Total } \\
\text { activity* }\end{array}$ & $\% \dagger$ & $\begin{array}{c}\text { Total } \\
\text { activity* }\end{array}$ & $\% \dagger$ \\
\hline Cytochrome $c$ oxidase & $5 \cdot 5$ & 24 & 17.4 & 76 & $12 \cdot 3$ & 27 & $32 \cdot 4$ & 73 \\
\hline $\begin{array}{l}\text { Succinate cytochrome } c \\
\text { reductase }\end{array}$ & 0.7 & 18 & $3 \cdot I$ & 82 & $x \cdot 6$ & 30 & 3.7 & 70 \\
\hline $\begin{array}{l}\mathrm{NADH}_{2} \text { cytochrome } c \\
\text { reductase }\end{array}$ & $5 \cdot 2$ & 27 & $13 \cdot 8$ & 73 & I 2 & 26 & 35 & 74 \\
\hline $\mathrm{NADH}_{2}$ oxidase & $12 \cdot 8$ & 38 & $20 \cdot 7$ & 62 & 12 & 40 & I 8 & 60 \\
\hline NAD-malic dehydrogenase & 54 & 70 & 23 & 30 & 233 & 74 & 80 & 26 \\
\hline NADP-isocitrate dehydrogenase & $2 \cdot 6$ & 53 & $2 \cdot 3$ & 47 & $7 \cdot 0$ & 79 & $1 \cdot 9$ & $2 \mathrm{I}$ \\
\hline Aconitase & $5 \cdot 8$ & 62 & $3 \cdot 6$ & 38 & 26 & 76 & 8 & 24 \\
\hline Fumarase & $9 \cdot 6$ & 60 & $6 \cdot 3$ & 40 & - & - & - & - \\
\hline
\end{tabular}

* Specific activity multiplied with the amount of protein in the fraction.

$\dagger$ Distribution of total activity between the $10,000 \mathrm{~g}$ supernatant and $10,000 \mathrm{~g}$ sediment as a percentage of the sum.

Enzymes of the citric acid cycle. The specific activities of the enzymes of the citric acid cycle found in homogenates and fractions of anaerobically and aerobically grown baker's yeast and brewer's bottom yeast are shown in Table 3. The activities of these enzymes were also observed to increase on transfer from anaerobic growth conditions to the aerobic stationary phase, but here the differences relating to the growth conditions were smaller than those occurring in the electron-transport enzymes. Thus, NADmalic dehydrogenase, NADP-isocitrate dehydrogenase, aconitase and fumarase were of the same order of magnitude in anaerobically as well as in aerobically grown log.phase cells of baker's yeast. The reduction of the glucose concentration only partly increased the activities in the aerobic exponential phase. The specific activity of NAD- 
malic dehydrogenase increased to Io-fold, while NADP-isocitrate dehydrogenase and aconitase rose only to 2-fold in aerobically grown baker's yeast in the stationary phase. In brewer's bottom yeast the corresponding increase of activity was proporrionally larger because of the very low activity of the enzymes of the citric acid cycle in anaerobically grown brewer's bottom yeast.

Table 3. Specific activities of some enzymes of the citric acid cycle in homogenates and subcellular fractions of baker's yeast and brewer's bottom yeast, grown under varying conditions

\begin{tabular}{|c|c|c|c|c|}
\hline & $\begin{array}{l}\text { NAD- } \\
\text { malic } \\
\text { dehydro- } \\
\text { genase }\end{array}$ & $\begin{array}{l}\text { NADP- } \\
\text { isocitrate } \\
\text { dehydro- } \\
\text { genase }\end{array}$ & Aconitase & Fumarase \\
\hline \multicolumn{5}{|l|}{ Baker's yeast } \\
\hline Seed yeast homogenate & $0.167^{*}$ & 0.010 & 0.035 & - \\
\hline $\begin{array}{l}\text { Anaerobic culture } \\
\text { Homogenate } \\
\text { 10,000 } \mathrm{g} \text { sediment } \\
\text { I0,000 } \mathrm{g} \text { supernatant }\end{array}$ & $\begin{array}{l}0.126 \\
0.852 \\
0.063\end{array}$ & $\begin{array}{l}0.018 \\
0.096 \\
0.013\end{array}$ & $\begin{array}{l}0.134 \\
0.140 \\
0.072\end{array}$ & $\begin{array}{l}0.227 \\
0.454 \\
0.089\end{array}$ \\
\hline $\begin{array}{l}\text { Aerobic, middle expone } \\
\text { Homogenate } \\
\text { I0,000 } g \text { sediment } \\
\text { I0,000 } g \text { supernatant }\end{array}$ & $\begin{array}{l}\text { hase }{ }^{\circ} \\
0.14 \mathrm{I} \\
0.350 \\
0.099\end{array}$ & $\begin{array}{l}0.018 \\
0.094 \\
0.007\end{array}$ & $\begin{array}{l}0.078 \\
0.234 \\
0.048\end{array}$ & $\begin{array}{l}0.197 \\
0.836 \\
0.118\end{array}$ \\
\hline $\begin{array}{l}\text { Aerobic, exponential ph } \\
\text { Homogenate } \\
\text { I0,000 } g \text { sediment } \\
\text { I0,000 } g \text { supernatant }\end{array}$ & $\begin{array}{l}0.994 \\
\mathrm{I} .666 \\
0.853\end{array}$ & $\begin{array}{l}0.036 \\
0.033 \\
0.037\end{array}$ & $\begin{array}{l}0.085 \\
0.200 \\
0.061\end{array}$ & - \\
\hline $\begin{array}{l}\text { Aerobic, stationary pha } \\
\text { Homogenate } \\
\text { I0,000 } \mathrm{g} \text { sediment } \\
\text { I0,000 } \mathrm{g} \text { supernatant }\end{array}$ & $\begin{array}{l}I \cdot 424 \\
5 \cdot I \text { I } 4 \\
I \cdot I 26\end{array}$ & $\begin{array}{l}0.039 \\
0.145 \\
0.031\end{array}$ & $\begin{array}{l}0.327 \\
4 \cdot 728 \\
0 \cdot 200\end{array}$ & - \\
\hline Brewer's bottom yeast & & & & \\
\hline $\begin{array}{l}\text { Anaerobic culture } \\
\text { Homogenate } \\
\text { I0,000 } \mathrm{g} \text { sediment }\end{array}$ & $\begin{array}{l}0.135 \\
0.028 \\
0.033\end{array}$ & $\begin{array}{l}0.008 \\
0.013\end{array}$ & $\begin{array}{l}0.043 \\
0.045\end{array}$ & - \\
\hline $\begin{array}{l}\text { Aerobic, exponential ph } \\
\text { Homogenate } \\
\text { I0,000 } \mathrm{g} \text { sediment }\end{array}$ & $\begin{array}{l}0.027 \\
0.015\end{array}$ & $\begin{array}{l}0.006 \\
0.015\end{array}$ & $\begin{array}{l}0.026 \\
0.050\end{array}$ & - \\
\hline $\begin{array}{l}\text { Aerobic, stationary pha } \\
\text { Homogenate } \\
\text { I0,000 } g \text { sediment } \\
\text { I0,000 } g \text { supernatant }\end{array}$ & $\begin{array}{l}I \cdot 45 \text { I } \\
2 \cdot 560 \\
0 \cdot 468\end{array}$ & $\begin{array}{l}0.023 \\
0.042 \\
0.007\end{array}$ & $\begin{array}{l}0.066 \\
0.125 \\
0.014\end{array}$ & - \\
\hline
\end{tabular}

* Specific activities expressed as $\mu$ moles of transformed substrate per minute per mg. protein. $5 \%$ (initial conc.) sucrose used as carbon source.

$\dagger$ Actual carbon source concentration about $2 \%$.

$\$$ Actual carbon source concentration about $0.6 \%$.

It is interesting to note the considerable activity of the enzymes of the citric acid cycle in baker's yeast, occurring even under anaerobic growth conditions with low activity of electron-transport enzymes and no developed mitochondria. Similar conclusions have been reached by Jayaraman et al. (1966) from studies on the glucose repression. They found that the $\mathrm{NADH}_{2}$ oxidase is subject to strong repression while 
mitochondrial malic dehydrogenase appears less sensitive. Polakis et al. (1965) suggest as a possible explanation that enzymes of the citric acid cycle are necessary for amino acid and protein synthesis even under conditions where mitochondria and electrontransport enzymes are not needed for energy production because of the abundant energy supply from glycolysis.

NAD-malic dehydrogenase was observed to be the most active of the enzymes of the citric acid cycle, which apparently means participation in the regulatory mechanisms. NAD-isocitrate dehydrogenase was present in baker's yeast in smaller amounts than the NADP-linked enzyme; under anaerobic conditions the specific activity was 0.002 in the homogenate and 0.008 in the $10,000 \mathrm{~g}$ sediment. The specific activity of the enzymes of the citric acid cycle reached a maximum in the $10,000 \mathrm{~g}$ sediment and the activity depended on the growth conditions in the same way as in the homogenate. Contrary to the electron-transport enzymes, the bulk of the total activity of the enzymes of the citric acid cycle was found in the post-mitochondrial supernatant, while the $10,000 \mathrm{~g}$ sediment contained $20-40 \%$ (Table 2). Schatz et al. (1963) have reported that the sediment obtained by centrifugation of baker's yeast homogenate at $26,300 \mathrm{~g}$ for $15 \mathrm{~min}$. contained $14 \%$ of the total fumarase activity, $13 \%$ of the aconitase and $8 \%$ of the NAD-malic dehydrogenase activities. A similar result was obtained by us as regards the distribution of the above enzymes in the mitochondrial and cytoplasmic fractions, although the portion of the $10,000 \mathrm{~g}$ sediment was clearly larger. Duell et al. (1964) have isolated the mitochondrial fraction of yeast by means of the spheroplast method. They found that the fraction contained about $26 \%$ of the NAD-malic dehydrogenase activity, while the bulk appeared in the post-mitochondrial supernatant, an observation that agrees well with our results. The location of isocitrate dehydrogenase in the yeast cell has not previously been investigated. In assays on animal cells it has been found that the soluble fraction contained $80 \%$ of the NADPlinked enzyme, while the mitochondrial fraction contains only I2 \% (Hogeboom \& Schneider, 1950). In yeast, NADP-isocitrate dehydrogenase was likewise found mainly in the cytoplasmic fraction (Table 2). The enzymes of the citric acid cycle and the electron-transport enzymes had a different intracellular distribution and their activities depended on the growth conditions in different ways. The enzymes of the citric acid cycle have a synthetic function beside their role in energy production and are for the most part soluble. The synthesis of these enzymes is not as sensitive to glucose repression and oxygen induction as is the synthesis of the enzymes bound in the lipoprotein structures of mitochondria.

Oxidative properties and structure of the particles of the $10,000 \mathrm{~g}$ sediment. Particularly interesting are the properties of the particles of the $10,000 \mathrm{~g}$ sediment obtained from log.-phase yeast cells grown aerobically under glucose repression. The oxidative properties of the $10,000 \mathrm{~g}$ sediments prepared from middle log.-phase cells and from cells harvested during the stationary phase were compared (Table 4). As was previously observed in enzyme determinations, the uptake of oxygen when $\mathrm{NADH}_{2}$ was used as substrate was markedly higher than when succinate was used. With $\mathrm{NADH}_{2}$ the uptake of oxygen in the $10,000 \mathrm{~g}$ sediment obtained from the stationary phase was about Io-fold as compared with the uptake in the exponential phase. With succinate as substrate the corresponding increase was about 8-fold. The exogenous $\mathrm{NADH}_{2}$ cannot permeate into the animal mitochondria if these are intact, while the yeast mitochondria are able to rapidly oxidize $\mathrm{NADH}_{2}$, with a clear respiratory control 
(Ohnishi et al. 1966). Even on ethanol or lactate as substrate, the uptake of oxygen in the stationary phase rose about 3 -fold. However, it is to be noted that in several substrates the particles obtained at the exponential phase already had a respiratory control ratio of $\mathrm{I} \cdot 4$ to $\mathrm{I} \cdot 7$.

Table 4. Oxidative properties of the $10,000 \mathrm{~g}$ sediment isolated from baker's yeast at different aerobic growth phases

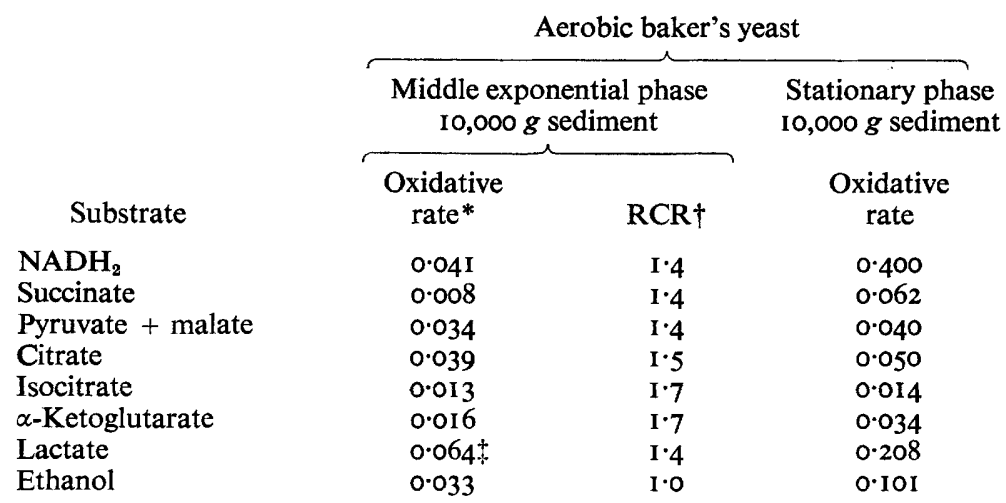

* $\mu$ atoms oxygen/min./mg. protein.

$\uparrow$ Respiratory control ratio, rate with ADP/rate without ADP.

$\$$ When $5 \mu \mathrm{g}$. $/ \mathrm{ml}$. antimycin A was added, the oxidative rate was 0.047 . On the other hand, antimycin A completely inhibited oxygen uptake with $\mathrm{NADH}_{2}$, succinate, pyruvate + malate or citrate as substrate, whether the sample was taken from the exponential or stationary phase.

As far as the mitochondria synthesis of Saccharomyces cerevisiae is known on the basis of electron micrographs Yotsuyanagi, 1962 and Wallace \& Linnane, 1964 showed that the $10,000 \mathrm{~g}$ sediment isolated from baker's yeast cells by the spheroplast method contained mitochondrial precursors of different stages when the yeast had been grown under anaerobic conditions. At the aerobic exponential phase the cells contained, in addition to the precursors, further developed mitochondria (Pl. I, fig. I). The mitochondria were not completely developed until the cells had reached the aerobic stationary phase. So the structure of the isolated particles correlates with what has been observed as regards the activities of the respiratory enzymes during oxygen adaptation under carbon source limited growth.

This work was reported at the $4^{\text {th }}$ meeting of the Federation of European Biochemical Societies, Oslo, 7 July I967 (Nurminen \& Suomalainen, 1967).

\section{REFERENCES}

Anfinsen, C. B. (1955). Aconitase from pig heart muscle. Meth. Enzymol. r, 695.

BigGs, D. R. \& LinNANE, A. W. (I963). The effect of oxygen on the composition and organisation of the electron transport system of yeast. Biochim. biophys. Acta $\mathbf{7 8 , 7 8 5 .}$

Chantrenne, H. (1955). Peroxydases induites par l'oxygène chez la levure. Biochim. biophys. Acta I8, 58 .

Cooperstein, S. J. \& Lazarow, A. (I95I). A microspectrophotometric method for the determination of cytochrome oxidase. J. biol. Chem. 189, 665 . 
Duell, E. A., INOUE, S. \& UTTER, M. F. (I964). Isolation and properties of intact mitochondria from spheroplasts of yeast. $J$. Bact. 88, 1762 .

Green, D. E. \& ZiegleR, D. M. (1963). Electron transport particles. Meth. Enzymol. 6, 416.

Hogeboom, G. H. \& Schnemer, W. C. (1950). Cytochemical studies of mammalian tissues. III. Isocitric dehydrogenase and triphosphopyridine nucleotide-cytochrome c reductase of mouse liver. J. biol. Chem. 186, 417.

Jayaraman, J., Cotman, C., Mahler, H. R. \& Sharp, C. W. (I966). Biochemical correlates of respiratory deficiency. VII. Glucose repression. Arch. Biochem. Biophys. II6, 224.

KoRNBERG, A. (1955a). Isocitric dehydrogenase of yeast (TPN), Meth. Enzymol. 1, 705.

KornberG, A. (1955b). Isocitric dehydrogenase of yeast (DPN). Meth. Enzymol. 1, 707.

LinNane, A. W., Vitols, E. \& Nowland. P. G. (1962). Studies on the origin of yeast mitochondria. J. cell. Biol. 13, 345 .

Mackler, B., Collipp, P. J., Duncan, H. M., Rao, N. A. \& Huennekens, F. M. (1962). An electron transport particle from yeast: purification and properties. J. biol. Chem. 237, 2968.

MAhler, H. R., MACKLER, B., GRANDChamp, S. \& SLonimski, P. P. (I964). Biochemical correlates of respiratory deficiency. I. The isolation of a respiratory particle. Biochemistry 3,668 .

Massey, V. (1955). Fumarase, Meth. Enzymol. 1, 729.

Nurminen, T., Oura, E. \& Suomalainen, H. (1965). Preparation of protoplasts from baker's yeast. Suomen Kemistilehti 38 B, 282.

Nurminen, T. \& SuOMALAINEN, H. (1967). Respiratory enzyme activities of anaerobically and aerobically grown baker's and brewer's yeast. Federation of European Biochemical Societies, Fourth Meeting, Oslo 1967, Abstr. Commun. p. II I.

OCHOA, S. (1955). Malic dehydrogenase from pig heart, Meth. Enzymol. r, 735.

Ohnishi, T., KaWaguchi, K. \& Hagihara, B. (1966). Preparation and some properties of yeast mitochondria. J. biol. Chem. 24I, 1797.

Polakis, E. S., Bartley, W. \& Meek, G. A. (1964). Changes in the structure and enzyme activity of Saccharomyces cerevisiae in response to changes in the environment. Biochem. J. 90, 369.

Polakis, E. S., Bartley, W. \& Meek, G. A. (I965). Changes in the activities of respiratory enzymes during the aerobic growth of yeast on different carbon sources. Biochem. J. 97, 298.

Rabinowitz, M. \& DeBernard, B. (1957). Studies on the electron transport system. X. Preparation and spectral properties of a particulate DPNH and succinate cytochrome $\mathrm{c}$ reductase from heart muscle. Biochim. biophys. Acta 26, 22.

RACKER, E. (1950). Spectrophotometric measurements of the enzymatic formation of fumaric and cis-aconitic acids. Biochim. biophys. Acta 4, 21 I.

RACUSEN, D. \& JoHNSTONE, D. B. (1961). Estimation of protein in cellular material. Nature, Lond. 191, 492.

SchatZ, G. (1963). The isolation of possible mitochondrial precursor structures from aerobically grown baker's yeast. Biochem. biophys. Res. Commun. 12, 448.

SchatZ, G. \& KLima, J. (1964). Triphosphopyridine nucleotide: cytochrome c reductase, of Saccharomyces cerevisiae: a 'microsomal' enzyme. Biochim. biophys. Acta 8r, 448.

Schatz, G., Tuppy, H. \& Klima, J. (1963). Trennung und Charakterisierung cytoplasmatischer Partikel aus normaler und atmungsdefekter Bäckerhefe. Z. Naturforsch. $18 b$, I45.

Schuurmans Stekhoven, F. M. A. H. (1966). Studies on yeast mitochondria. I. Existence of three phosphorylation sites along the respiratory chain of isolated yeast mitochondria. Arch. Biochem. Biophys. 115, 555.

Suomalainen, H., Nurminen, T. \& OURA, E. (1967). Leakage of some enzymes and cofactors from the cell during the preparation of protoplasts from baker's yeast. Arch. Biochem. Biophys. 118, 219.

TUSTANOFF, E. R. \& BARTLEy, W. (1962). Development of respiration in anaerobically grown yeast. Biochem. J. 84, 40 P.

Wallace, P. G. \& LinNANE, A. W. (1964). Oxygen-induced synthesis of yeast mitochondria. Nature, Lond. 201, II9I.

WhITE, J. (1954). Yeast Technology, p. I04. London: Chapman and Hall.

VITOLS, E. \& LiNNANE, A. W. (196I). Studies on the oxidative metabolism of Saccharomyces cerevisiae. II. Morphology and oxidative phosphorylation capacity of mitochondria and derived particles from baker's yeast. J. biophys. biochem. Cytol. 9, $70 \mathrm{I}$. 


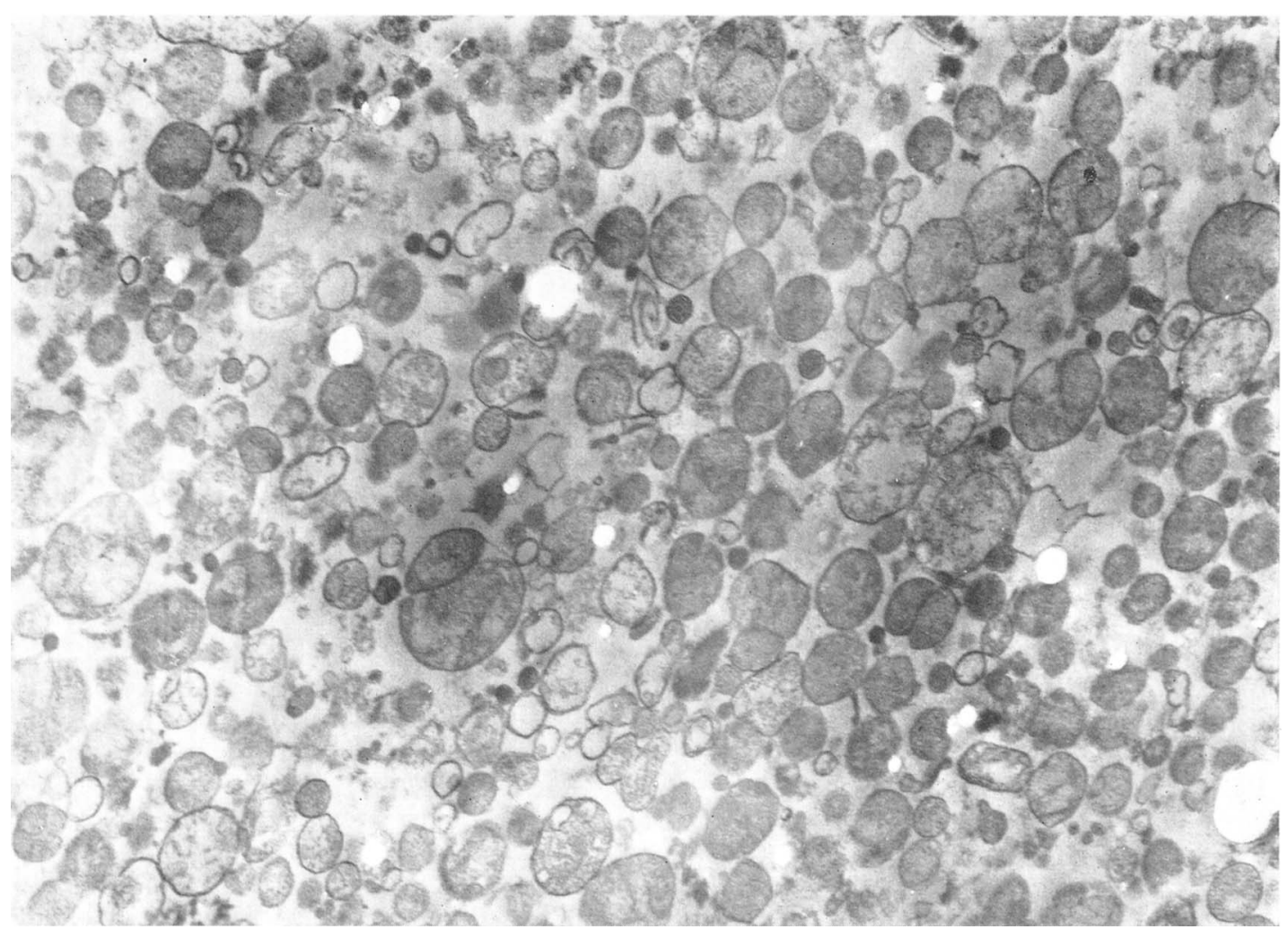


Vitols, E., North, R. J. \& LinNane, A. W. (196I). Studies on the oxidative metabolism of Saccharomyces cerevisiae. I. Observations on the fine structure of the yeast cell. J. biophys. biochem. Cytol. 9, 689.

Yonetani, T. \& Ray, G. S. (I965). Studies on cytochrome oxidase. J. biol. Chem. 240, 3392.

YotsuyanaGi, Y. (1962). Études sur le chondriome de la levure. I. Variation de l'ultrastructure du chondriome au cours du cycle de la croissance aérobie. J. Ultrastruct. Res. 7, $12 \mathrm{I}$.

\section{EXPLANATION OF PLATE}

Fig. I. 10,000 $\mathrm{g}$ sediment isolated from baker's yeast cells grown aerobically to the mid-exponential phase. $\times 10,000$. 